\title{
The use of pulverized wastes of basalt production as a filler of gypsum compositions
}

\author{
Victoria Petropavlovskaya ${ }^{1}$, Andrey Pustovgar $^{2}$, Aleksandr $_{\text {Buryanov }}^{2}$, Tatiana \\ Novichenkova ${ }^{1}$ and Mariya Zavad'ko ${ }^{1}$ \\ ${ }^{1}$ Tver State Technical University, 170026, 22, Afanasiy Nikitin Embankment, Tver, Russia \\ ${ }^{2}$ Moscow State University of Civil Engineering, Yaroslavskoe shosse, 26, Moscow, 129337, Russia
}

\begin{abstract}
These studies are aimed at improving the performance of gypsum materials and products by using in their composition waste production of basalt fibers. The purpose of this study is to prove the possibility of using waste production of basalt fibers as a filler in gypsum composites. As the main materials used gypsum binder (Samara), as well as waste production of basalt fibers (Tver production). The positive effect of the waste is due to the participation of soluble minerals of basalt in the processes of hardening of gypsum binder. Also, the waste particles form a more perfect structure of gypsum stone., filling the pore space. It is revealed that the use of waste production of basalt fibers is advisable to use as a filler in gypsum composites.
\end{abstract}

\section{Introduction}

The creation of safe materials that meet modern requirements for energy efficiency is one of the main tasks of construction at the present time. That is why building materials made of gypsum are gaining popularity. Production of gypsum materials does not require a lot of energy and is safe, as well as the materials obtained. However, such materials have low strength. The task of scientists is to increase the strength of materials based on gypsum, while maintaining their environmental friendliness and safety at all stages. The paper studies the possibility of increasing the strength of gypsum composites by introducing a filler in the form of waste. Waste production of basalt fibers at the moment is not utilized, while it has similar properties as the fiber itself. Basalt itself is durable, has stable properties, resistant to aggressive environments. This makes the use of waste the most attractive.

In works [1-3] V. D. Sekerin prospects of use of waste of basalt production as components of new construction materials are considered. However, such problems as heterogeneity of waste composition and low bulk density are touched upon. Such problems undoubtedly make it difficult to use waste as a filler.

In work [4] of the same author, such important aspect as decrease in Prime cost due to involvement of waste in repeated production is considered.

In the work of $\mathrm{V}$. Yu. Alexandrov [5, 7] the possibility of using the waste of production of plates of basalt fiber is considered. The author defines the main properties of the waste, as well as the prospects of its use as a component of asphalt concrete. 
The authors of work [6, 10] studied the influence of fibers, including basalt, on the properties of gypsum cement-pozzolanic binder. In the presence of basalt fiber, the authors observed an increase in strength, water resistance and corrosion resistance of the compositions.

In work [7, 11, 12-15] the data obtained from 1993 to 2016 on the topic of basalt fibers from the point of view of different areas are considered. This work is interesting because it summarizes and summarizes data from 78 theses on this topic.

It was found that the gypsum composite properties are improved by obtaining of denser particle packing in the presence of finely dispersed particles in the system $[8-9,12,15]$.

\section{Methods}

The studies used gypsum astringent $\alpha$-modification of gypsum plant in Samara. The water demand of the binder grade G-16 was 35-40\%, the beginning of setting - no earlier than 4-5 minutes, the end of setting-no later than 20 minutes, the compressive strength-16 MPa, bending-6-7 MPa. As a filler waste of production of the Tver was used. A comparative analysis of the chemical composition of the waste and basalt fiber is shown in table 1 .

This waste is represented by various minerals of the plagioclase group: anorthite, calcite, quartz, etc. the mass of dust-like basalt of glass wool, in addition, is permeated with crystals of plagioclase, pyroxene (Fig. 1). The structure of basalt fiber is shown in Fig. 2.

Table 1. Basalt chemical composition.

\begin{tabular}{|c|c|c|}
\hline Oxide & Content in waste, $\%$ & $\begin{array}{c}\text { Content in basalt fiber, } \\
\%\end{array}$ \\
\hline $\mathrm{SiO}_{2}$ & 48,78 & 52,67 \\
\hline $\mathrm{MgO}$ & 10,99 & 9,06 \\
\hline $\mathrm{CaO}$ & 9,05 & 13,91 \\
\hline $\mathrm{Fe}_{2} \mathrm{O}_{3}$ & 7,38 & 6,87 \\
\hline $\mathrm{Na}_{2} \mathrm{O}$ & 6,87 & 1,58 \\
\hline $\mathrm{Cl}$ & 5,73 & - \\
\hline $\mathrm{K}_{2} \mathrm{O}$ & 4,39 & 0,57 \\
\hline $\mathrm{Al}_{2} \mathrm{O}_{3}$ & 3,05 & 12,14 \\
\hline $\mathrm{TiO}_{2}$ & 0,201 & 1,10 \\
\hline
\end{tabular}

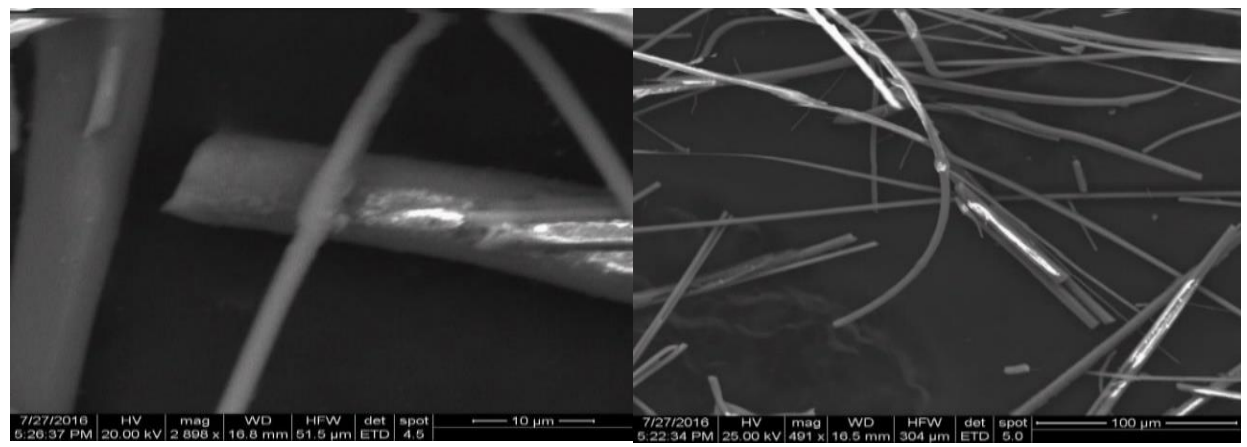

Fig.1. Microstructure of basalt waste.

The granulometric composition of the waste was determined by laser diffraction on a laser microanalyzer particle size "Analysette 22". 
According to the particle size distribution (Fig. 2) basalt waste is dominated by macroparticles. According to the differential and integral distribution, the dust-like composition has a single-modal distribution of basalt particles by size. The form factor of the integral distribution-3.5. The particle sizes included in the waste are presented in table 2 .

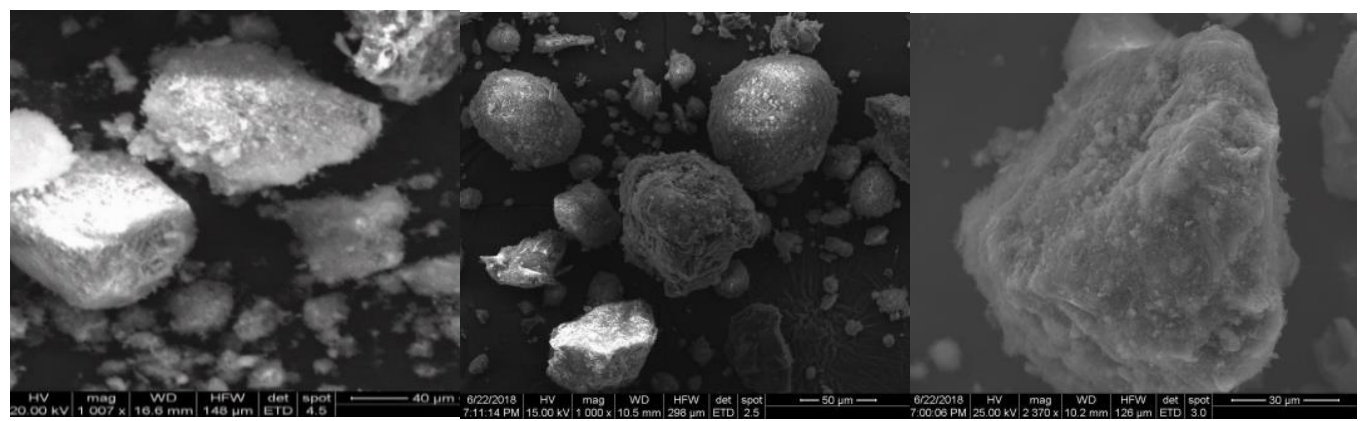

Fig. 2. Microstructure of basalt fiber.
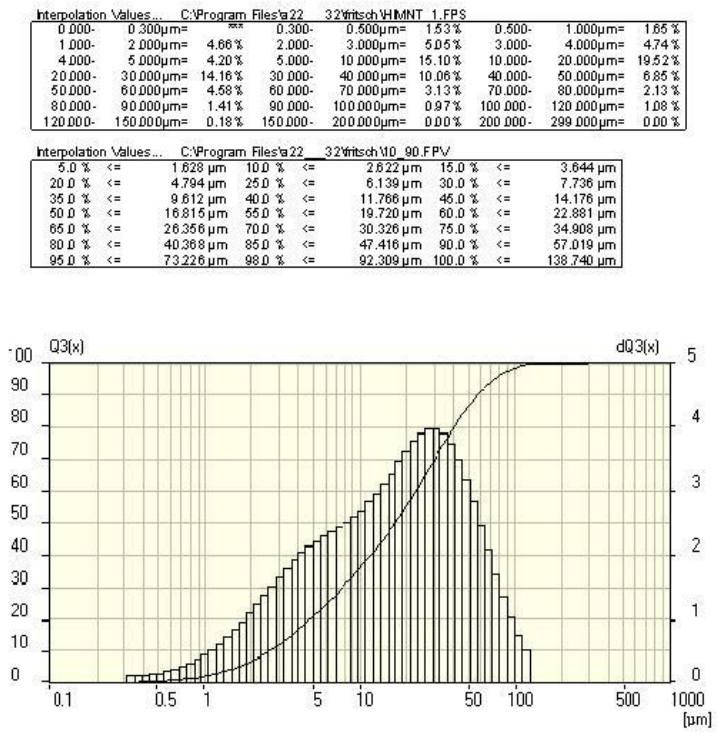

Fig. 3. Integral and differential distribution curves of dust-like basalt waste.

Table 2. Dispersion characteristics.

\begin{tabular}{|c|c|c|}
\hline $\begin{array}{c}\text { Maximum particle size } \\
(\mathrm{d} 98), \mathrm{mkm}\end{array}$ & $\begin{array}{c}\text { Average particle size (d50), } \\
\mathrm{mkm}\end{array}$ & $\begin{array}{c}\text { The content of particles less } \\
\text { than } 2, \mathrm{mkm}, \%\end{array}$ \\
\hline 92,309 & 16,815 & 7,84 \\
\hline
\end{tabular}

The electrical conductivity of the solutions was determined by the conductometer "KSL-101". Gypsum plaster G-16, waste production of basalt fibers were mixed in a dry state, and then shut with water. Electrical conductivity measurements of the obtained solutions were carried out at an interval of 0.033 hours.

The study of the impact of waste on the physical and mechanical characteristics of the gypsum composites produced on the samples-beams 40 x 40x $160 \mathrm{~mm}$, according to GOST 
23789. The water-gypsum ratio varied from 0.36 to 0.375 in increments of 0.05 . The percentage of the binder mass of basalt waste varied from 6 to $10 \%$ every $2 \%$.

\section{Research result}

As a result of solubility studies, it was found that the electrical conductivity of solutions depends on the dust content,the maximum electrical conductivity was revealed at $10 \%$ of the additive content (Fig. 4). Within 16 minutes, a small electrical conductivity is achieved (Fig. 5).

The greatest value of bending strength is achieved when the content of waste in an amount of $10 \%$ and is $7.96 \mathrm{MPa}$, the average density of the stone at the same time -1687 $\mathrm{kg} / \mathrm{m} 3$, porosity $-37.52 \%$ (Fig. 6). Compressive strength of composites was $43.29 \mathrm{MPa}$ at a waste content of the same in the amount of $10 \%$, which is the highest indicator (Fig. 7). The optimal water-gypsum ratio for composites with $10 \%$ of the waste is -0.365 .

As part of this work, the values of alkalinity of gypsum binder solutions, waste and mixtures based on them, with an optimal content of waste were investigated. It was found that alkaline basalts affect the structure of the modified gypsum stone. $\mathrm{pH}$ modified gypsum is reduced to 6.53 , pure gypsum -6.99 , and waste -6.22 .

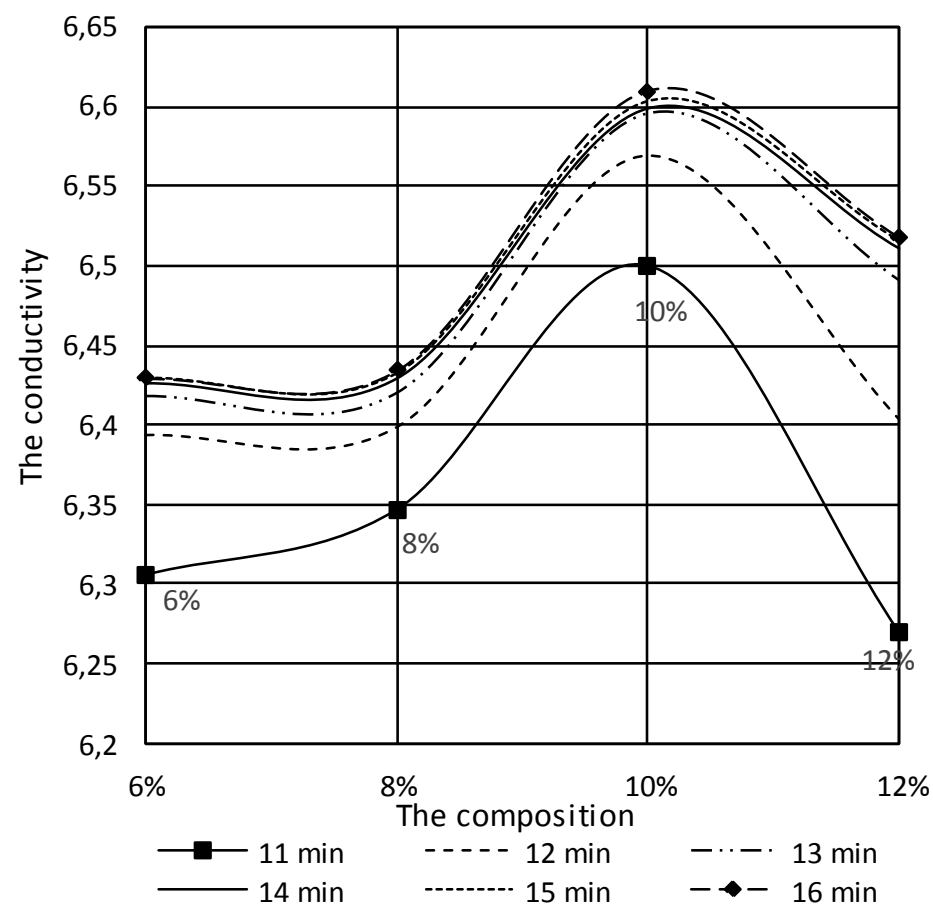

Fig. 4. The dependence of the electrical conductivity of solutions with different percentage of waste time. 


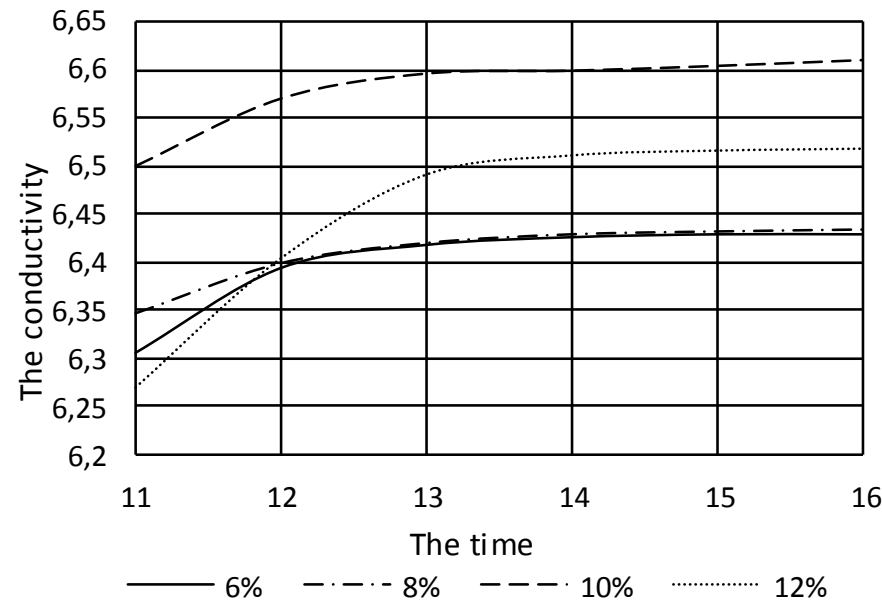

Fig. 5. Dependence of electrical conductivity on the content of waste.

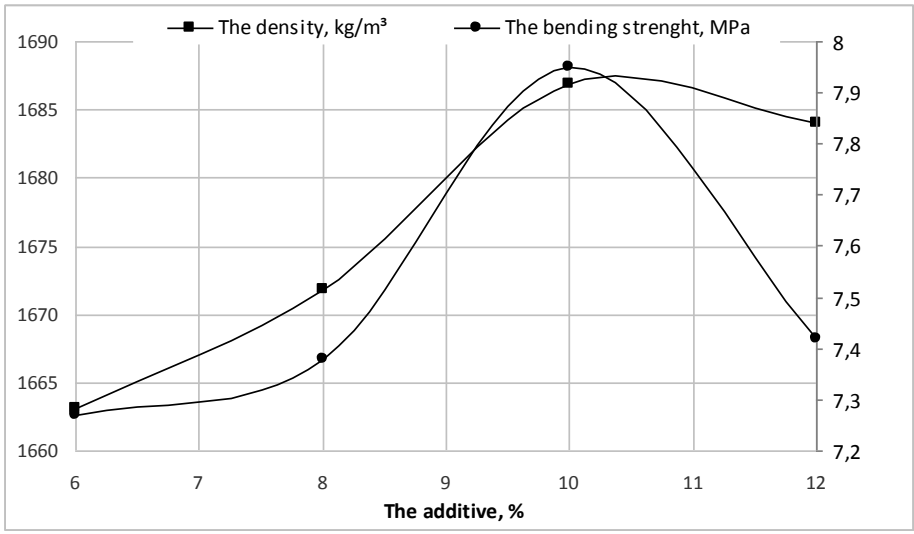

Fig. 6. Effect of additives on the strength and the density.

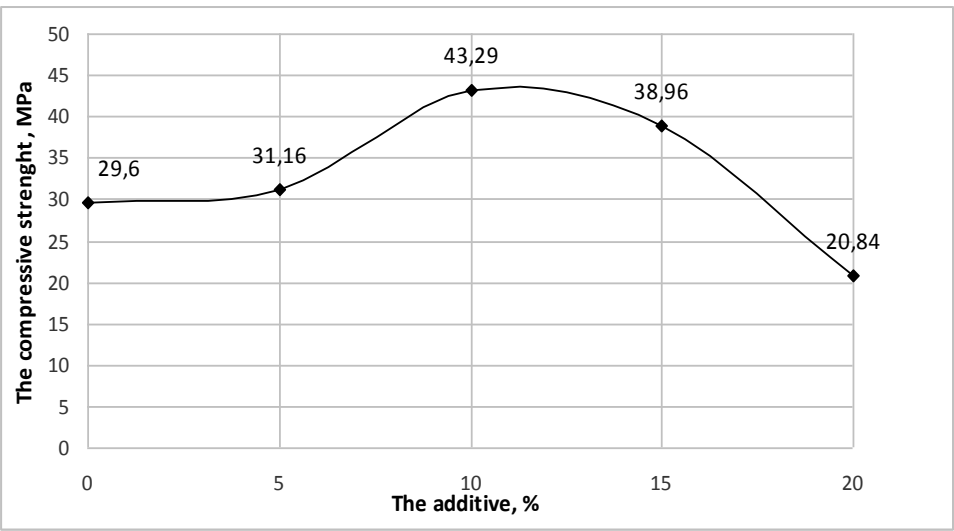

Fig. 7. Effect of additives on the compressive strength 


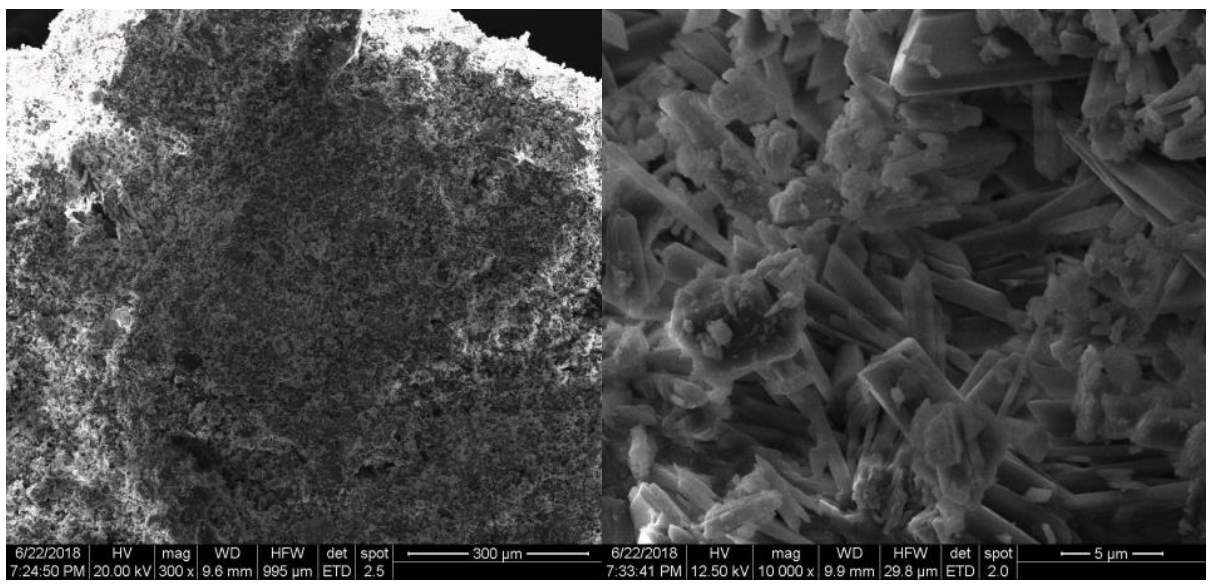

Fig. 8. The microstructure of gypsum with additive waste.

The increase in strength properties of gypsum composites with the use of basalt waste as a filler is explained by the chemical participation of soluble minerals of basalt in the formation of new phases during the hardening of the gypsum binder. Also, the positive effect of the waste is due to the fact that the basalt particles contribute to a denser packaging of the resulting material with the filling of its pore space.

\section{References}

1. V.D. Sekerin, A.E. Gorohova, E.N. Novikova, Ekonomika i predprinimatel'stvo 8 (73) (2016)

2. V.D. Sekerin, Izvestiya Moskovskogo gosudarstvennogo tekhnicheskogo universiteta, 2 (24) (2015)

3. V.D. Sekerin, E.N. Novikova, Materials of the International scientific and practical conference of department" Economy and organization of production", (2015)

4. H.A. Hezhev, Yu.V. Puharenko, T.A. Hezhev, Stroitel'nye Materialy 11, (2013)

5. D.Yu. Aleksandrov, Materials of the International scientific and practical conference of students, graduate students and young scientists (2017)

6. E.N. Potapova, A.S. Manushina, A.V., Uspekhi v himii $i$ himicheskoj tekhnologii, 7 (2016)

7. N.E. Ablesimov, YU. G. Malova, Nauchnoe obozrenie. Tekhnicheskie nauki, 6 (2016)

8. 8. V.B. Petropavlovskaya, T.B. Novichenkova, A.F. Buryanov, V.N. Solov'ev, K.S. Petropavlovskii, Vestnik MGSU, 12 (2017)

9. A.S. Manushina, A.V. Urbanov, M.S. Zyryanov, A.O. Sapronov, E.N. Potapova, Uspekhi v himii i himicheskoj tekhnologii, 1 (2017)

10. N.E. Ablesimov, YU. G. Malova, Nauchnoe obozrenie. Tekhnicheskie nauki, 6 (2016)

11. A.F. Buryanov, T.B. Novichenkova, V.B. Petropavlovskaya, K.S. Petropavlovskii MATEC Web Conf., 117 (2017)

12. K.A. Saraykina, V.A. Golubev, G.I. Yakovlev, S.V. Sychugov, G.N. Pervushin, Stroitel'nye Materialy, 1-2 (2016)

13. O.V. Artamonova Sintez nanomodifitsiruyushchikh dobavok dlya tekhnologii stroitel'nykh kompozitov, (2016)

14. A.V. Knotko, A.A. Meledin, V.V. Sudin, A.V. Garshev, V.I. Putlyaev, Stroitel'nye Materialy, 9 (2010)

15. G.M. Rahimova, A.S. Arinova, A.M. Rahimova, M.A. Han, Trudy Universiteta. 2 (63) (2016) 